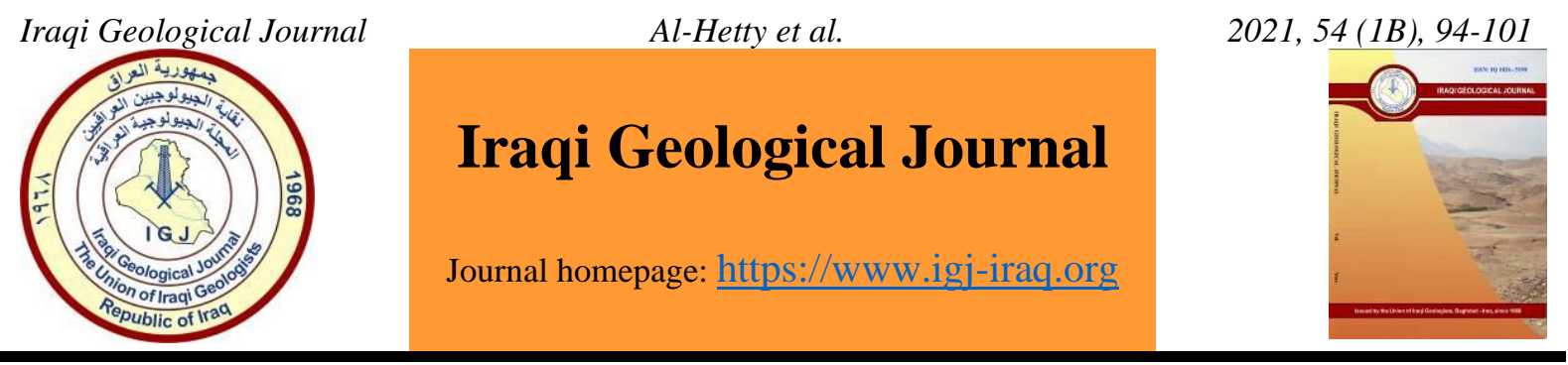

\title{
Description of the Karst Phenomena Spreading Along Stratified Sequence in the Western Desert of Iraq
}

\author{
Salam O. Al-Hetty ${ }^{1}$, Amer S. Al-jibouri ${ }^{1, *}$ and Ali M. Abed ${ }^{1}$ \\ ${ }^{1}$ Department of Applied Geology, College of Science, University of Anbar, Ramadi, Iraq \\ *Correspondence: sc.aalgibouri@uoanbar.edu.iq
}

Received: 6 August 2020; Accepted: 17 December 2020; Published :28 February 2021

\begin{abstract}
The study focused on two important sites containing many caves sites located in the west of Al Anbar Governorate. The first site is Um El-Githoaa cavity in Hit region, a cave or trunks was chosen to show the aesthetic of this cave in terms of its shape and dimensions. The maximum diameter is $22.1 \mathrm{~m}$, while the perpendicular diameter is $18.5 \mathrm{~m}$. It is a dome shape and the height of its roof reaches about $2 \mathrm{~m}$ located in the stratigraphic sequence falls within the massive gypsum, Fatha Formation (Middle Miocene). Geoelectrical exploration was chosen on the southern side of the cave to check whether the sinkholes scattered in the area are connected to subsurface caves or not. Using a Dipole-dipole array was chosen along a traverse, shown there are three sub-surface caves. This indicates that these phenomena are widespread in the region. The second location is Haditha, Barwana Village which was chosen to study where the cave is located in unconformity breccia zone between Anah Formation (Upper Oligocene- Lower Miocene) and Euphrates Formation (Lower Miocene- Middle Miocene). Barwana cave extends to the north $30 \mathrm{~m}$ and then tends to the west extend about $1 \mathrm{~km}$ within fragile breccia layer with incoherent components and ends with a small opening at the Euphrates River. This phenomenon was not present in the hard gypsum rocks in the Hit region, it was observed to have a large oval shape.
\end{abstract}

Keywords: Karst; Um El-Githoaa cavity; Barwana cave; Dipole-dipole array; Formation

\section{Introduction}

The western regions of Iraq include karst regions of various forms, distinct and aesthetic. It can be tourist resorts of great importance to attract large numbers of tourists. Karst is a type of natural phenomenon that usually arises within carbonate rocks (limestone, dolomite) or evaporates (gypsum, anhydrite, rock salt); any terrain where change removable rocks are soluble above and below the ground by water soluble carrying distinctive characteristics of relief and drainage. It is estimated that natural phenomena karst occupies up to $10 \%$ of the Earth's surface, and that up to a quarter of the world's population is provided with water karst (Jennings, 1971). It has been also taken in many countries of the world as distinct tourism facilities. In Iraq, the southern part of Al-Jazeera, along the left bank of the Euphrates River large caves is formed in gypsum beds of the Fatha Formation and carbonate rock of the Euphrates Formation. The Fatha Formation represents a closed shallow basin which had been isolated from the Tethys Sea during the Middle Miocene. Basically, gypsum is an evaporate mineral that usually precipitates closed or semi-closed shallow water (Awadh and Al-Ankaz, 2016). Few kilometers north of Hit a large cave (Um El-Githoaa cavity) is formed also in the gypsum beds of the plateau that borders

DOI: $\underline{10.46717 / i g j .54 .1 B .8 M s-2021-02-26}$ 
Euphrates valley. The zone is composed of limestone fragments derived from the Anah Formation, cemented by carbonates that vary between $0-8 \mathrm{~m}$ in thickness. Sissakian et al. (2005) mapped 43 sinkholes to relate the formation of the sinkhole to the exposure of the brecciate zone and underlying Anah Formation. This layer lies below the Euphrates Formation, which is considered to be of the same age. The Euphrates Formation (Lower Miocene) deposited in a shallow environment composing of dolomitic, fossiliferous, and oolitic limestone with green marls at the top (Awadh and Al-Owaidi, 2020). The authors dated the karsting to Pliocene or even the end of Miocene. Between Al-Baghdadi and Haditha simple and complex caves are common. The shape of the sinkholes and caves in the limestone is homogeneous and has close dimensions, and a long horizontal extension below the surface may exceed a kilometer compared to those found within gypsum rocks. In the carbonate rocks, the depth of these caves ranges $(10-35) \mathrm{m}$ in the Haditha region, western Iraq. The depth in gypsum ranges 1-15 $\mathrm{m}$, some ancient karsts may reach a diameter of a few kilometers, and a depth of 10-15 $\mathrm{m}$ in the southern desert, Iraq (Hamza, 1997; Sissakian et al., 2005). Tens of simple caves were observed along the left cliff of the Euphrates River within Haditha town. These caves have single rooms of each cave and Barwana cavity within Haditha city is an important one of these caves.

Geophysical studies carried out in the study area by Abed, (2013) also Thabet and Abed, (2013). They study the differences between the techniques of 2D imaging resistivity and the Bristow method in detecting the exact dimension of subsurface cavities which is located within the Hit and Haditha area, western Iraq. The Dipole-dipole array (n-factor $=6$ and 8$)$, Wenner-Schlumberger $(n=8)$ and Poledipole $(\mathrm{n}=8)$ arrays are executed along traversal above Um El- Githoaa cavity in the Hit region. The Dipole-dipole array is applied again along a traverse in Haditha region above WadhahaShamut cavity. (Abed, 2015) applied the Graphite Bristow method over the K-3 cavity to evaluate the method of depicting a relatively large natural cavity. The result of the extension of the cave is about $58.6 \mathrm{~m}$ and depth to the cavity bottom of $33.5 \mathrm{~m}$, with an error of no more than $3 \%$ in depth and $2 \%$ in height. Salman et al. (2020a) examined weak underground areas represented by fractures and caves in gypsum soil in the university of Anbar, using the electrical resistivity method as an economic solution. Reverse models clearly show that the difference in resistivity between the anomalous part of the weak and the background region, Salman et al. (2020b) concluded that the 2D imaging survey using Dipole-dipole array is a useful technique and more operative for determining and mapping the subsurface weak zones (fractures and cavities), when taken into consideration using the suitable a-spacing and $\mathrm{n}$-factor for each electrodes array, especially with the Dipole-dipole array which provides the best imaging of the subsurface weak zones. This result was obtained by comparing it with the other electrode arrays. Abed, et al. (2020) obtained the results of the 2D and 3D resistivity inverse models using Dipole-dipole array within the University of Anbar site. They are good subsurface images of the heterogeneity in the hardness of the soil components and the voids within it, and the top layer of clay. The aim of this study is to describe the karst region within the stratigraphic sequence of the Western Sahara region.

\section{Site Description}

In the southern part of Al-Jazeera district along the left bank of the Euphrates River, large caves formed in gypsum beds of the Fatha Formation (Middle Miocene) and carbonate rock of the Euphrates Formation (Jassim and Goff, 2006). A large cave, Um El-Githoaa cavity, is formed in the gypsum beds of the Fatha Formation within the plateau that borders Euphrates valley, north of Hit city. Barwana cavity in Barwana city within Haditha area formed within the Euphrates Formation (Lower Miocene), within carbonate sediments (Fig. 1). 


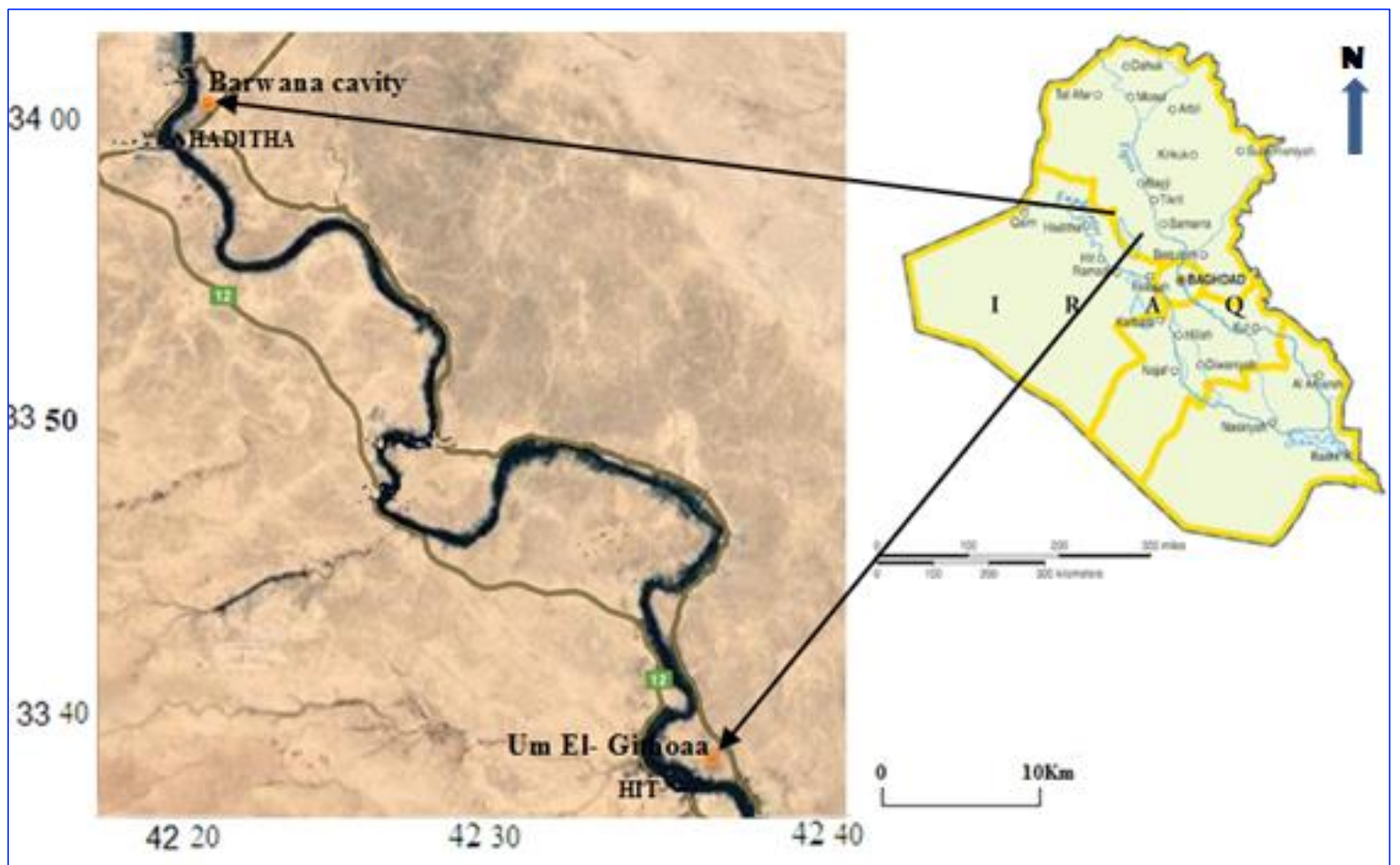

Fig. 1. Map of the study area

The emergence of the Fatha Formation (Middle Miocene) in large parts of the western desert areas (Jassim and Goff, 2006). It is developed east of the Euphrates River, especially along Al-Tharthar Lake. The thickness of this member ranges (20-30) m. It consists of marl, limestone, gypsum, claystone, siltstone, and sandstone. The Anah Formation was defined by Bellen et al. (1959) from the Euphrates valley about $15 \mathrm{~km}$ west of Al-Nahiyah village near Anah (Al-Ghreri, 2007). The type section comprises grey brecciated recrystallized, detrital, and coralline limestone. The Euphrates Formation is the most widespread formation of the sequence. Two supplementary type sections were described in Wadi Chabbab, $39 \mathrm{~km}$ west of Anah, and in Wadi Rabi, $20 \mathrm{~km}$ of Husaiba. The first section is $110 \mathrm{~m}$ thick and represents the lower and middle units of the formation. The second is $25 \mathrm{~m}$ thick and represent the upper unit of the formation The combined section comprises Lower unit: $20 \mathrm{~m}$ thick basal conglomerate sub rounded boulder and cobbles of limestone derived from the underlying Oligocene Anah Formation, followed by $10 \mathrm{~m}$ of recrystallized fossiliferous limestone grading into coralline limestone. Middle unit: 90m of hard, fossiliferous limestone and pseudo-oolitic limestone beds. Along the Euphrates River, between Al-Qaim and Busaya, this unit inters fingering with the Ghar Formation. Upper unit: 25m thick soft, fossiliferous bluish green marl, interbedded with thin beds of shelly, recrystallized limestone or shelly oolitic limestone. This is most widespread Miocene unit occurring along, and west of, the Euphrates River. The bedding in the limestone is often contorted especially along the Abu Jir fault. This contorted bedding may have formed soon after sedimentation due to fluid movement or mud thixotropic due to earthquake along the fault (Jassim and Goff, 2006).

\section{Materials and Methods}

The information acquisition process included two stages. First establishment of a stratigraphic column for the sedimentary succession in two locations through field measurements. As it represents the first stratigraphic column for the sequence of rock layers Fatha Formation north Hit city. Where the height of Um El- Githoaa cave room was determined within the stratigraphic sequence, which was equal to $2.0 \mathrm{~m}$. The second stratigraphic column represents the stratigraphic sequence of Anah and Euphrates 
formations. This sequence included the Barwana cave, which reached a height of $1.45 \mathrm{~m}$. The second stage was the geoelectrical survey, along line of $38 \mathrm{~m}$ length. Two-dimension resistivity imaging survey with electrode spacing of $2 \mathrm{~m}$. The Terrameter SAS 4000 instrument used to measure 2-D resistivity data. Choosing this array because it can provide a better depiction of the cavity under the surface by comparing it to other arrays (Nyquist et al., 2007; Thabitand Abed, 2013). One hundred sixty-eight measurements of apparent resistivity were taken for this line. 2D resistivity imaging measurements were processed using the RES2DINV program version 3.71.118 (Geotomo Software, 2012). Forward modeling method and non-linear least-squares optimization techniques were applied for processing and inversion the apparentdata (Loke, 2000).

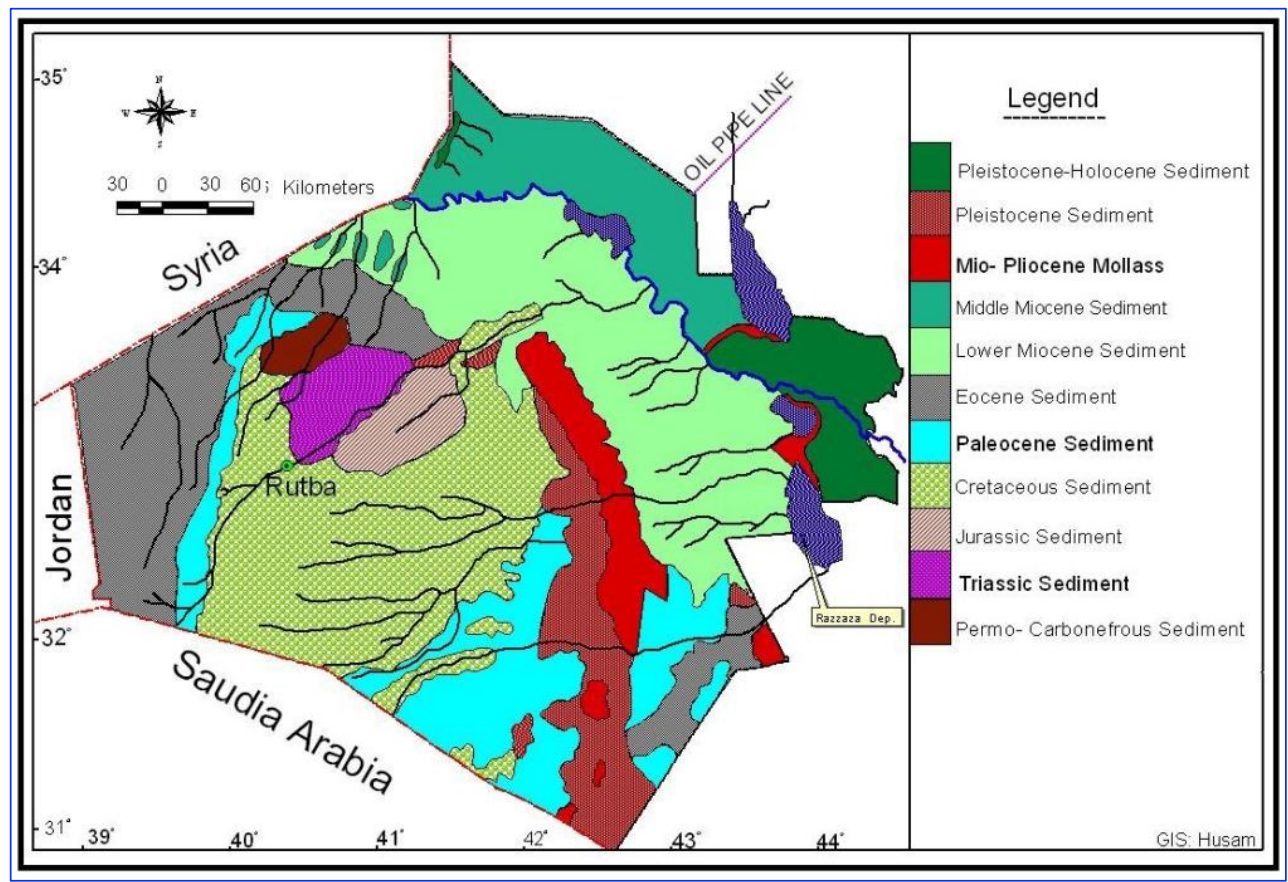

Fig. 3. Geological map of Al-Anbar government (Sissakian and Salih, 1994)

\section{Results and Discussion}

Two caves were chosen in the study area, which are Um El- Githoaa and Barwana. The first located in the Hit area within gypsum rocks, and the second in the Barwana area, Haditha region, within the carbonate rocks. It involved working to create a stratified column at each cave in order to locate the cave from the stratigraphic sequence. Dimensions of the cave were taken and the description of the cave room was made in terms of geological features and sedimentary structures.

\subsection{Um El- Githoaa Cavity in Hit Area}

Um El-Githoaa cave is one of the important tourist areas in the Hit region. The stratigraphic sequence in this cavity in the strike region represents the formation of the slit (Middle Miocene). In the field, it was observed that the cave was based on Marley limestone intertwined with gypsum rocks, while the cave room was located inside a huge layer of plaster. The cave chamber was formed as a result of the melting of gypsum rocks by the groundwater heading towards the Euphrates valley and the seepage of rainwater from the surface (Fig. 4). The dimensions of the cave were measured. Through field measurements it was found that the maximum diameter is $22.1 \mathrm{~m}\left(260^{\circ}\right.$ direction), while the perpendicular diameter is $18.5 \mathrm{~m}$. It is a dome in shape and the height of its roof reaches about $2 \mathrm{~m}$. The roof thickness of the cavity is equal nearly to $3.8 \mathrm{~m}$ and to the bottom $6 \mathrm{~m}$. 


\begin{tabular}{|c|c|c|c|c|}
\hline$\stackrel{8}{4}$ & 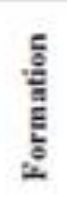 & 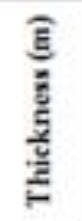 & 量 & Descriptions \\
\hline 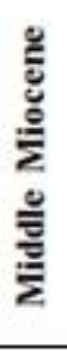 & 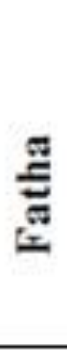 & $\begin{array}{l}6.8 \\
1 \\
\end{array}$ & 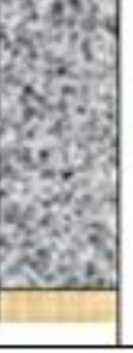 & $\begin{array}{l}\text { Massive gypsum bed in white color, site of } \\
\text { Um El-Githoaa cave } \\
\text { Yellowish marly limestone interbedded } \\
\text { with thin beds of gvpsum }\end{array}$ \\
\hline
\end{tabular}

Fig. 4. Stratigraphic column at Um El- Githoaa cavesite

Um El- Githoaa cave is characterized by several phenomena such as:

- Stalagmite \&Stalactite

Stalagmite where the drops reach the ground, the resulting precipitate builds a cone pointing upward. If the height between the ceiling and the ground is too small, it may happen that the stalagmites and stalactites form a column that can gradually thicken the column (Jennings, 1971).

- Fistula deposit is formed when the stalactite caused by a very low flow.

- Flowstone.

It is a cloth-like leaves of gypsum wraps the cave wall if groundwater flows along the surface of the wall. In addition, when water flows instead of flowing directly from the exhibition ceiling, it flows along the wall; concrete construction can give very different shapes reminiscent of curtains (Fig. 5).
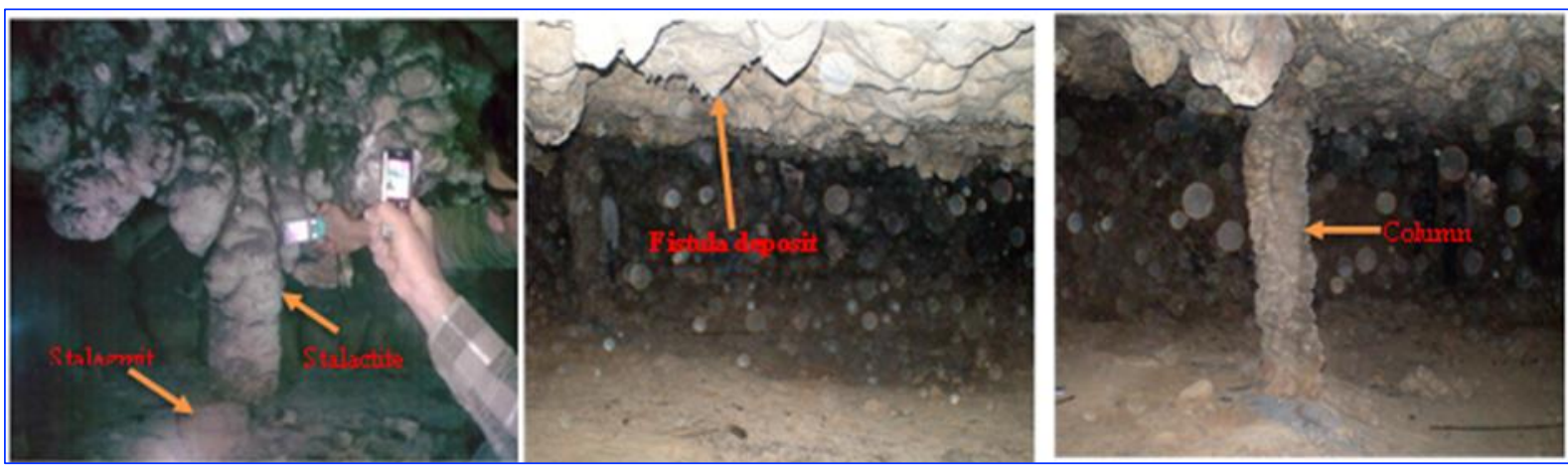

Fig. 5. Stalactite, stalagmite, column and fistula deposit features in Um El- Githoaa cave

\subsection{Southern Um El- Githoaa Cave Site}

2D resistivity imaging survey has been done to know the nature of the neighboring region. An electric exploration on the southern side of the cave was chosen to investigate any cavity connected to the sinkholes which has been noted near the cave. As a Dipole-dipole array was adopted for its effectiveness in picking caves and fractures (Abed, 2013). The inversion results of 2D imaging Dipoledipole data along the traverse as shown in (Fig. 6), it clearly indicates that the resistivity contrast between the anomalous part of cavity and background resistivity. The robust inversion option was used in this study. The robust inversion method is usually used because it is best for investigating sharp boundaries and caves and spaces below the surface (Loke, 2020). The figure shows three caves that are close to the surface: the first on the right extends $4 \mathrm{~m}$ and one meter height. The second is in the middle, and its length is $4.5 \mathrm{~m}$, and its height is $2 \mathrm{~m}$. As for the third cave, it extends $3.5 \mathrm{~m}$ and $2 \mathrm{~m}$ height. This leads 
to conclude that the area contains many subterranean caves, and confirms many small sized sinkholes spread in the area. This indicates that these phenomena are widespread in the region. These appearances add to the region additional aesthetic and add to the interests of tourists.

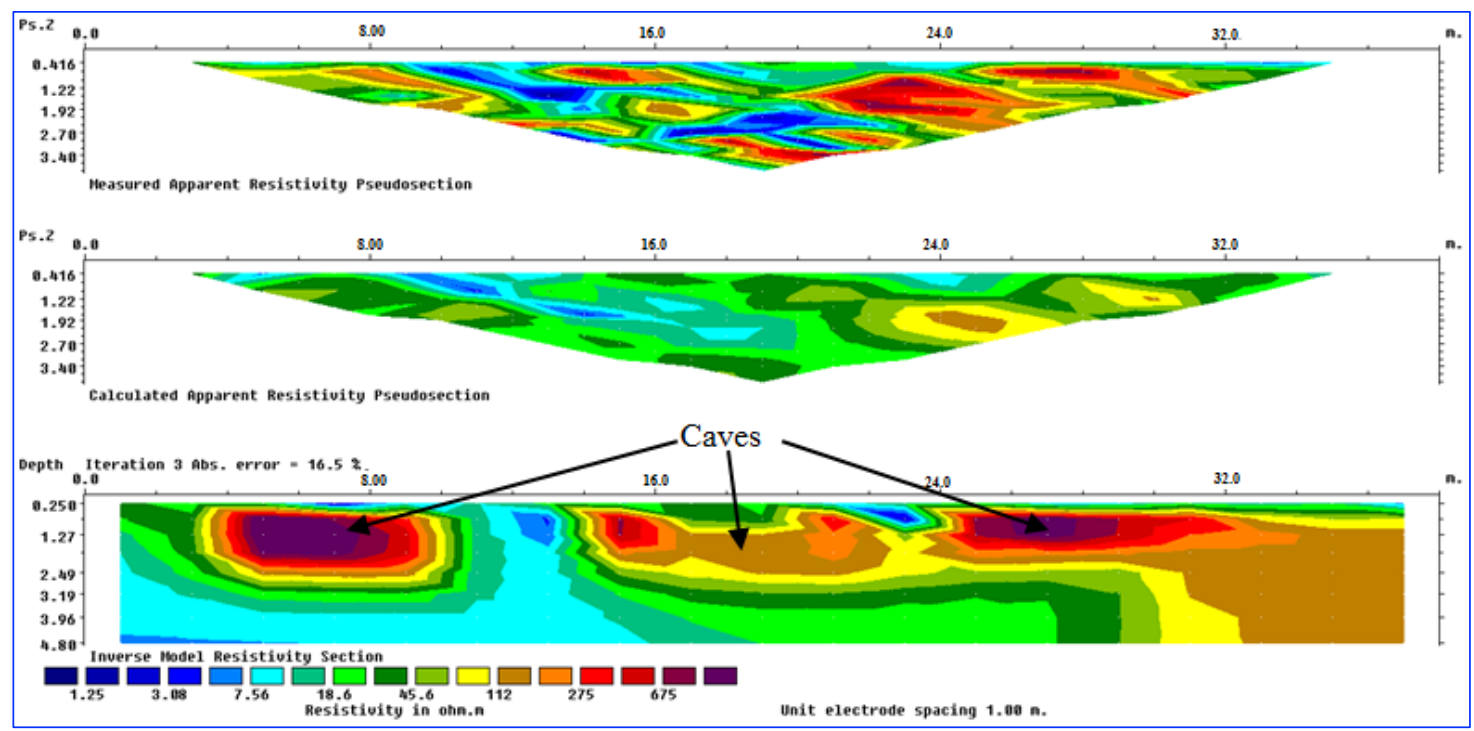

Fig. 6. The inversion results of $2 \mathrm{D}$ imaging Dipole-dipole data along the traverse, southern

Um El-Githoaa cave site

\subsection{Barwana Cavity in Haditha Area}

This cavity is located within Barwana village in Hadithaarea which is situated in an area surrounded by the limestone of the Euphrates Formation. The cave is located within the unconformity breccia layer above the Anah Formation. Barwana cavity's depth from surface to roof is $5.6 \mathrm{~m}$ and to the bottom is $7.3 \mathrm{~m}$. The width of this cavity is $9.2 \mathrm{~m}$. The cave extends to a distance of $30 \mathrm{~m}$ and then it turns towards the west. The necessary measurements were made to create a stratum column showing the cave located within the Brescia layer, which represents the area of mismatch between the Anah and Euphrates formations as shown in Fig. 7.

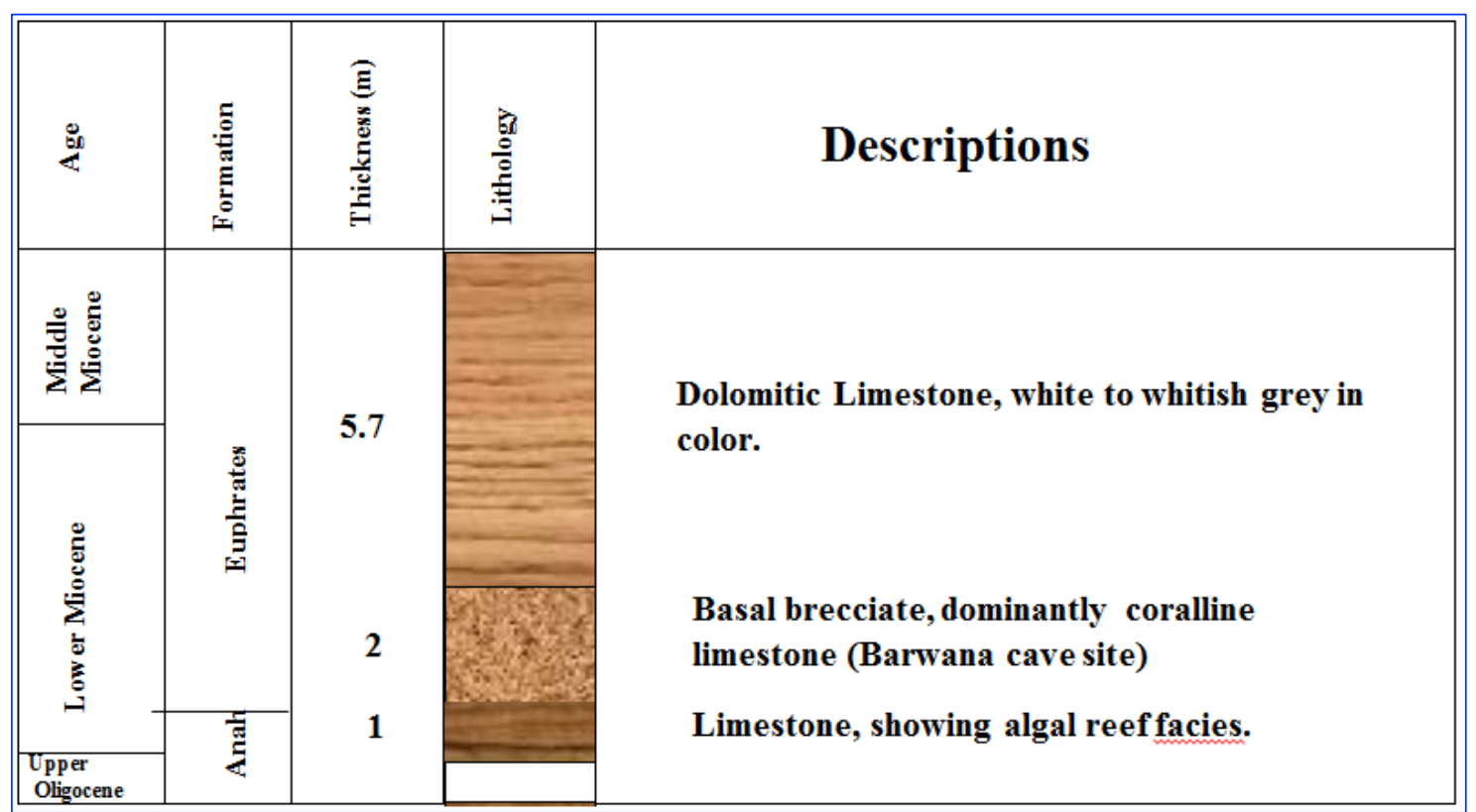

Fig. 7. Stratigraphic column at Barwana cave site 


\subsection{Comparison Between Caves in Carbonate Rocks and Gypsum Rocks}

The comparison between caves in carbonate rocks and gypsum rocks is evident through the current study, through the study of the caves of Um El-Githoaa and Barwana. Barwana cave extends to $30 \mathrm{~m}$ north and then tends to the west to extend about a kilometer and ends with a small opening at the Euphrates River. This phenomenon was not present in the gypsum caves in the Hit region. The reason is due to the nature of the rocks in which these caves were formed. Barwana Cave is due to melting of the fragile breccia layer with incoherent components due to the infiltration of groundwater and infiltration rain, which extends along the boundary between Anah and Euphrates formations, which led to its extension for long distances. While the gypsum caves were observed to have a large oval shape. These caves were formed as a result of the dissolution of hard gypsum rocks through the infiltration of rainwater from cracks and fractures extending to the surface.

\section{Conclusions}

A stratigraphic column was established in each cave to delineate the diameter of $22.1 \mathrm{~m}$ (direction $260^{\circ}$ ) and a minimum diameter of $18.5 \mathrm{~m}$. It is located within massive gypsum and slit formation (Middle Miocene) and geoelectrical exploration has been carried out in the southern side of the cave to verify whether the sewers spread in the area are connected to subterranean caves or not. The result of a dipole array showed three caves below the surface. This indicates the spread of these phenomena in the region. The second location is Haditha, Barwana Village. Barwana Cave is located within unconformity breccia layer between the Anah Formation (Upper Oligocene-Lower Miocene) and Euphrates Formation (Lower MioceneMiddle Miocene). Barwana cavity's depth from the surface to the roof is $5.6 \mathrm{~m}$ and to the bottom is $7.3 \mathrm{~m}$. The width of this cavity is $9.2 \mathrm{~m}$. Barwana cave extends to the north 30 meters and then tends to the west to extend to about a kilometer and ends with a small opening at the Euphrates River. This phenomenon was not present in the gypsum caves in the Hit region. The cave is the result of the melting of the fragile breccia layer with incoherent components due to the infiltration of groundwater and infiltration rain, which extends along the boundary between Anah and the Euphrates Formations, which led to its extension for long distances. While the gypsum caves were observed to have a large oval shape. These caves were formed as a result of the dissolution of hard gypsum rocks through the infiltration of rainwater from cracks and fractures extending to the surface. These regions can be tourist resorts of great importance to attract large numbers of tourists. This is one of the most prominent geological tourism areas in Iraq.

\section{Acknowledgements}

Authors are very grateful to the Editor in Chief Prof. Dr. Salih M. Awadh, the Secretary of Journal Mr. Samir R. Hijab. and the Technical Editors for their great efforts and valuable comments.

\section{References}

Abed, A. M., 2013. Comparison Between 2D Imaging Survey and Traditional Electrode Arrays in Delineating Subsurface Cavities in Haditha-Hit Area (W Iraq), Ph. D. Thesis, University of Baghdad, Baghdad, Iraq. 
Abed, A. M., 2015. Evaluation of pole-dipole technique (Bristow's method) to detect the dimension of K-3cavein Haditha area, west Iraq, Case study, Kirkuk University Journal of Scientific Studies 10(3), 108-121.

Abed, A. M., Al-Zubedi, A. S., Abdulrazzaq Z. T., 2020. Detected of gypsum soil layer by using 2D and 3D electrical resistivity imaging Techniques in university of Anbar, Iraq, Iraqi Geological Journal 53 (2C), 134-144

Al-Ghreri, M. F. T., 2007. Biostratigraphic succession of the formations in the upper Euphrates valley in the area between Hit and Al-Qaim. Ph. D. Thesis, Department of Geology, College of Science, University of Baghdad.

Awadh, M A., Al-Ankaz, Z. S., 2016. Sulfur isotopes geochemistry of the bituminous Fatha evaporates in Fatha formation, Hit-Abu Jir area, Western Iraq, Iraqi Geological Journal 39-49 (2), 34-45

Awadh, S. M., Al-Owaidi, M. R. A., 2020. Application of triangles method for quantitative estimation of marl reserve in Euphrates Formation, Middle of Iraq. Iraqi Geological Journal 53 (2A), 35-49.

Bellen, R. C., Dunnington, H. V., Wetzel, R., Morton, D., 1959. Lexique Stratigraphique International, Asia, Fasc., 10a, Iraq, Paris.

Geotomo Software, 2012. RES2DINV ver.3.71.118, Rapid 2-D resistivity \&IP inversion using the least -squares method, geoelectrical imaging 2-D\&3D Penang, Malaysia, 133p.

Hamza, N. M., 1997. Geomorphology map of Iraq explanatory text, series of geological maps of Iraq (GEOSURV), sheet No. 3 (first edition), 47p.

Jassim, S. Z., Buday, T., 2006. Geology of Iraq. Dolin, Prague and Moravian Museum, Berno, 341pp.

Jennings, J. N., 1971. Karst (An Introduction to Systematic Geomorphology, Vol. 7). Cambridge, Mass. and London: MIT Press.

Loke, M. H., 2000. Electrical imaging surveys for environmental and engineering studies, A Practical guideto 2 Dand 3D surveys, $67 \mathrm{p}$.

Loke, M. H., 2020. Tutorial: 2D and 3D electrical imaging surveys, Geophysics 10(4), 339-349

Nyquist, J. E., Pcake, J. S., Roth, J. S., 2007. Comparison of an optimized resistivity array with dipole-dipole sounding in karst terrain. Geophysics 72: 139.

Salman, A. M, Abed, A. M., Thabit J. M., 2020. Comparison between Dipole-dipole and Pole-dipole arrays in delineation of subsurface weak zones using $2 \mathrm{~d}$ electrical imaging technique in Al-Anbar University, Western Iraq, Iraqi Journal of Science 61 (3), 567-576.

Salman, A. M, Thabit J. M., Abed, A. M., 2020. Application of the electrical resistivity method for site investigation in University of Anbar, Al-Ramadi City, Western Iraq, Iraqi Journal of Science 61(6), 13451352.

Sissakian, V.K., Ibrahim, E., Ibrahim, F., AL-Ali, N., 2005. Explanatory of Geological Hazard Map of Iraq 1st Edition, (Scale 1:1000000) D. Geol. Surv. (GEOSURV) Min. Invest, Baghdad.

Sissakian, V.K., Salih, S. M.,1994. The Geology of Ramadi, Area. Map-NA- 38-9 (GM-18) Scale 125000, GEOSURV. Unpublished Internal Report.

Thabit, J. M., Abed, A. M., 2013. Evaluation of different electrode arrays in delineation subsurface cavities by using 2D imaging technique, Journal of Univ. of Anbar for pure Science7 (3), 166-175. 